\title{
Pelatihan Manajemen Waktu dalam Mewujudkan Produktivitas Kerja pada Tenaga Kesehatan RSU Bhakti Asih
}

\author{
Roni Fadli ${ }^{*}$, Anggada Bayu Seta ${ }^{2}$, Nurul Ilham $^{3}$, Siti Nurcahayati $^{4}$, \\ Sri Mulyani ${ }^{5}$ \\ 1,2,3,4,5 Program Studi Manajemen, Fakultas Ekonomi, Universitas Pamulang \\ Jl. Surya Kencana No.1, Pamulang Barat, Kec. Pamulang \\ Kota Tangerang Selatan, Banten 15417 \\ *Penulis Korespodensi: dosen02328@unpam.ac.id
}

\begin{abstract}
ABSTRAK
Mitra dalam program ini adalah RSU. Bhakti Asih. Masalah utama yang dihadapi oleh mitra adalah rumah sakit masih belum dapat mengelola manajemen waktu dengan baik dan mengarahkan manajemen waktu yang optimal dan efisien. Belum matangnyamperencanaan kegiatan dan tugas anda yang maksimal agar mreka saling melengkapi sehingga penggunaan waktu akan menjadi lebih baik. Ditemukannya tenaga kesehatan yang bekerja di bawah tekanan yang tinggi sehingga anda dapat terhindar dari stres. Belum adanya skala prioritas dalam pekerjaan yang dijalani oleh tenaga kesehatan rumah sakit yang berdampak pada ketidakjelasan pekerjaan masing-masing individu sehingga menghasilkan produktivitas yang kurang maksimal. Hal ini harus harus diselesaikan mengingat akan menghambatnya pelayanan di rumah sakit. Kata Kunci : Manajemen Waktu, Produktivitas Kerja
\end{abstract}

\begin{abstract}
The partner in this program is RSU. Bhakti Asih. The main problem faced by partners is that the hospital is still unable to manage time management properly and direct optimal and efficient time management. The immature planning of your activities and tasks is not yet complete so that they complement each other so that the use of time will be better. The discovery of health workers who work under high pressure so you can avoid stress. The absence of a priority scale in the work undertaken by hospital health workers that have an impact on the obscurity of each individual's work resulting in sub-optimal productivity. This must be resolved because it will hamper service in hospitals.
\end{abstract}

Keywords: Time Management, Work Productivity

\section{PENDAHULUAN}

Manajemen waktu juga merupakan cara atau metode perencanaan dan pengorganisasian dalam memanfaatkan waktu untuk kegiatan tertentu yang sudah direncanakan dan harus diselesaikan dalam jangka waktu yang sudah ditetapkan (Maryadi, 2018). Jadi manajemen waktu juga mengacu pada cara mengatur dan merencanakan berapa lama menghabiskan waktu untuk kegiatan tertentu. Tujuan 
manajemen waktu adalah seseorang harus memiliki target atau tujuan yang hendak dicapai saat menjalankan semua pekerjaan yang sudah direncanakan tersebut (Nurhidayati, 2016). Sehingga waktu akan digunakan seefektif dan seefisien mungkin. Manajemen waktu yang baik memungkinkan seseorang untuk bekerja lebih cerdas, sehingga bisa menyelesaikan pekerjaan yang lebih banyak dalam waktu yang lebih singkat, bahkan ketika dalam keadaan tekanan tinggi. Jika gagal mengelola waktu maka bisa merusak keefektifan dan menyebabkan stres.

Banyak dari tenaga kesehatan produktivitas kerjanya menurun karena tidak bisa mengelola waktu dengan baik dan benar. Hal itu berkaitan dengan sikap kerja yang merupakan kesediaan untuk bekerja bergiliran, dapat menerima tambahan tugas, bekerja dalam suatu tim. (Sedarmayanti, 2001 : 71). Kata sikap berasal dari bahasa Latin Aptus, yang berarti "kecocokan" atau "kesesuaian". Sikap sebagai salah satu variabel dari faktor psikologis yang mempengaruhi perilaku konsumen memiliki keterkaitan yang kuat. Perilaku dapat memperkuat atau memperlemah sikap, sedangkan sikap sendiri dapat digunakan sebagai alat untuk memprediksi kecenderungan konsumen dalam memutuskan pilihan produk/jasa. (Sunarto, 2003:160).

Pengertian lain manajemen waktu adalah suatu kemampuan untuk mengalokasikan waktu dan sumber-sumber untuk mencapai tujuan (Dejanasz, 2002: 66). Keterampilan dalam mengelola waktu adalah bagaimana kita meluangkan waktu untuk memprioritaskan dan mencapai

beberapa tujuan kehidupan serta menghasilkan kesejahteraan. Manajemen waktu merupakan keterampilan personal dan manajerial. Hal ini merupakan proses untuk menyusun dan mencapai tujuan, memperkirakan waktu dan sumber-sumber waktu yang dibutuhkan untuk mencapai masing-masing tujuan dan mendisiplinkan diri sendiri memfokuskan pada tujuan. Seorang manajer yang efektif dapat mengelola waktu sehingga dapat meningkatkan produktivitas. Selain itu, manjemen waktu dapat mengurangi tingkat stress (Dejanasz, 2002: 66).

Rumah Sakit Umum Bhakti Asih adalah rumah sakit yang berada di Karang Tengah, Tangerang. Rumah Sakit Umum Bhakti Asih ini merupakan rumah sakit tipe C. Rumah sakit ini melayani pasien asuransi. Rumah Sakit Umum Bhakti Asih memulai operasionalnya pada Tanggal 10 Februari 2005, sebelumnya yaitu pada tahun 1993 berupa poliklinik spesialis 24 jam yang terus berkembang sehingga menjadi sebuah Rumah Sakit.

Visi Rumah Sakit Umum Bhakti Asih : menjadi Rumah Sakit yang terbaik dan terpercaya dalam pelayanan kesehatan di Provinsi Banten pada tahun 2018. Misi Rumah Sakit Umum Bhakti Asih : meningkatkan kompetensi SDM melalui pertumbuhan dan pengembangan keterampilan,

pengetahuandan attitude sesuai dengan standar kompetensi nasional dan internasional, menyelenggarakan pelayanan bermutu yang mampu memberikan kepuasan pelanggan dan berorientasi kepada kepentingan pelanggan dengan mengutamakan keselamatan pasien, mengelola keuangan secara profesional, meningkatkan kesejahteraan pegawai.

Berangkat dari latar belakang tersebut, tim Dosen dari Program Studi manjemen Universitas Pamulang mengadakan kegiatan Pengabdian kepada Masyarakat dengan bermitra bersama RSU. Bhakti Asih untuk dapat memberikan pelatihan bagi tenaga kesehatan. Selagi tim Dosen memberi pelatihan manajemen waktu kepada para tenaga 
Roni Fadli, dkk

kesehatan, para perangkat stakeholder rumah sakit dapat mengadaptasi proses pelatihan yang dilakukan tim dosen, hingga ke depannya program pelatihan ini dapat berkelanjutan.

\section{METODE PELAKSANAAN}

Metode pelaksanaan yang dilakukan dalam kegiatan pengabdian kepada masyarakat ini adalah meliputi kegiatan penyampaian materi manajemen waktu kepada tenaga kesehatan dengan metode yang komunikatif, yaitu ada penjelasan materi dan tanya jawab serta penerapan langsung materi yaitu dengan praktik sederhana dengan meliputi pemahaman ketika melakukan pelayanan di rumah sakit.

\section{HASIL DAN PEMBAHASAN}

Pelaksanaan kegiatan pengabdian masyarakat bertempat di RSU. Bhakti Asih berlokasi di karang tengah Ciledug Tangerang Selatan. Permasalahan yang dihadapi oleh RSU. Bhakti Asih saat ini terkait manajemen adalah adanya konflik yang timbul didalam tubuh organisasi yang disebabkan oleh beragam faktor. Beberapa fakta yang ditemukan terkait manajemen waktu yang ada didalam RSU. Bhakti Asih, bahwa rumah sakit masih belum dapat mengelola waktu dengan baik dan mengarahkan waktu yang tidak optimal menjadi menjadi optimal sehingga mewujudkan produktivitas kerja dengan cara mengelola waktu yang ada menggunakan stimulasi manajemen waktu.

Hal ini ditunjukan dengan masih dijumpainya kurangnya pelayanan yang sesuai dengan standar rumah sakit yang disebabkan oleh beberapa faktor dasar diantaranya yaitu, keterbatasan fasilitas kerja, adanya ketidakjelasan dalam menjalani pekerjaan yang dibebankan setiap individu, biasnya batasan wewenang dan tanggung jawab yang dimiliki oleh seorang tenaga kesehatan yaitu dimana ada pihak yang memasuki batasan pihak lain baik secara sengaja maupun tidak, yang berujung pada timbulnya ketegangan yang diantara pihak-pihak yang terlibat sehingga dapat mendorong timbulnya permasalahan pribadi.

\section{PENUTUP}

Kegiatan ini mendapat respons yang baik dari kordinator laboratorium RSU. Bhakti Asih, staff laboratorium, dan analis laboratorium di RSU tersebut. Tenaga kesehatan sangat antusias mengikuti proses pembelajaran yang disampaikan oleh tim Abdimas Program Studi Sastra Manajemen Universitas Pamulang.

Simpulan dari kegiatan pelatihan manajemen waktu untuk meningkatkan produktitas kerja ini adalah metode skala prioritas yaitu dalam melakukan aktifitas kerjanya para tenaga kesehatan memberikan pelayanan dengan cepat pada pasien yang butuh penanganan cepat sehingga dapat menunjang efisiensi waktu serta dituntut juga saling kerjasama antar satu sama lain yang berdampak pada peningkatan produktifitas kerja. 


\section{DAFTAR PUSTAKA}

Basu Swastha dan Irawan, 2005. Asas-asas Marketing. Jogjakarta : Liberty

De Janasz, Dwod, \& Schneider. 2002. Interpersonal Skills In Organization. New York : Mcgraw-Hill.

Gomes, Faustino Cardoso. 2003. Manajemen Sumber Daya Manusia. Jakarta: Andi Offset.

Griffin, 2004. Komitmen Organisasi. Terjemahan. Jakarta : Erlangga

Gumilar, I., Sunarsi, D. (2020). Comparison of financial performance in banking with high car and low car (Study of banks approved in the kompas 100 index for the period 2013-2017). International Journal of Psychosocial Rehabilitation. Volume 24 - Issue 7

Maryadi, T. (2018). Manajemen Waktu. Mmr Ugm. https://doi.org/12-31-8-12-2018

Muchdarsyah Sinungan, 2008. Produktivitas Apa dan Bagaimana. Jakarta: Bumi Aksara.

Nasution. 2007. Manajemen Industri. ed.1. Yogyakarta: Andi Press

Nurhidayati, D. D. (2016). Peningkatan Pemahaman Manajemen Waktu Melalui Bimbingan Kelompok Dengan Teknik Problem Solving pada Siswa. PSIKOPEDAGOGIA Jurnal Bimbingan Dan Konseling. https://doi.org/10.12928/psikopedagogia.v5i1.4592

Rozi, A., \& Sunarsi, D. (2020). The Influence of Motivation and Work Experience on Employee Performance at PT. Yamaha Saka Motor in South Tangerang. Jurnal Office, 5(2), 65-74.

Sedarmayanti, 2001. Sumber Daya Manusia dan Produktivitas Kerja. Jakarta : Mandar Maju

Sobarna, A., Hambali, S., Sutiswo, S., \& Sunarsi, D. (2020). The influence learning used $\mathrm{ABC}$ run exercise on the sprint capabilities. Jurnal Konseling dan Pendidikan, 8(2), 67-71.

Sunarsi, D. (2016, October). Pengaruh Minat, Motivasi Dan Kecerdasan Kognitif Terhadap Prestasi Belajar (Studi Kasus Pada Mahasiswa Program Studi S-1 Manajemen. Fakultas Ekonomi. Universitas Pamulang. Thn. Akademik 20152016). In Proceedings (Vol. 1, No. 1).

Sunarsi, D. (2018). Buku Ajar: Seminar Perencanaan Sumber Daya Manusia. Tangerang Selatan: Asmoro Mediatama

Sunarsi, D. (2019). Seminar Sumber Daya Manusia. Tangerang Selatan: Unpam Press

Sunarto. 2003. Manajemen Pemasaran. Yogyakarta: BPFE-UST.

Wibowo. 2011. Manajemen Kinerja. Jakarta: Raja Grafindo Persada. 